\title{
Sistem Pakar Pembagian Harta Waris Menurut Hukum Islam
}

\author{
Nur Aksin 1 , Rahmat Robi Waliyansyah², Nugroho Dwi Saputro ${ }^{3}$ \\ nuraksin69@gmail.com ${ }^{1}$, $\underline{\text { rahmat.robi.waliyansyah@upgris.ac.id }}^{2}$, nugputra1@gmail.com ${ }^{3}$ \\ 123 Universitas PGRI Semarang
}

\begin{abstract}
In general, Muslims regarding the distribution of inheritance and calculation procedures lack understanding and the difficulty of also getting experts in the field of inheritance distribution according to Islamic law (faraidh), this is an issue for the Muslim community, especially for heirs who want to divide inheritance according to law Islam. The author uses backward chaining methods in designing expert systems. The result of this research is the design of an expert system for dividing inheritance that can be used by the general public to help Islam solve the problem of calculation \& inheritance.
\end{abstract}

Keyword : Expert System, Backward Chainning, Inheritance, Faraidh

\begin{abstract}
Abstrak
Pada umumnya umat Islam mengenai pembagian harta waris dan tata cara penghitungan kurang memahami serta sulitnya juga mendapatkan pakar di bidang pembagian warisan menurut hukum Islam (faraidh), hal ini bagi masyarakat Islam menjadi sebuah permasalahan, terutama untuk ahli waris yang mau membagi harta warisan menurut hukum Islam. Penulis menggunakan metode metode backward chaining dalam merancang expert system. Hasil dari riset ini adalah rancangan sistem pakar untuk membagi warisan yang bisa dipakai oleh masyarakat umum untuk membantu menyelesaikan secara Islam permasalahan perhitungan \& pembagian waris.
\end{abstract}

Kata Kunci : Sistem Pakar, Backward Chainning, Harta Warisan, Faraidh 


\section{PENDAHULUAN}

Permasalahan keluarga terkait dengan membagi harta waris, bisa menjadi kompleks dimana para ahli waris ingin mengambil seluruhnya harta peninggalan, sehingga bisa menimbulkan kerugian untuk orang lain bahkan bisa menyebabkan timbulnya kriminalitas seperti perampokan dan pembunuhan (Rumambi, 2015). Selain itu dikarenakan oleh sifat rakus \& tamak, hal ini juga bisa terjadi disebabkan kurangnya pemahaman terkait pembagian harta warisan yang sesuai syariat Islam (Ardhilla \& Novrina, 2016). Permasalahan bisa bertambah rumit jika pembagiannya ditunda lebih lama atau meninggal dunianya beberapa ahli waris sebelum dibagikannya harta warisan, sehingga dbutuhkan perhitungan yang kompleks dan dasar pijakan hukum yang jelas pada saat akan dibagikan, sehingga pihak terkait tidak dirugikan (Tirkaamiasa \& Usino, 2015). Untuk menjaga kurukunan di dalam keluarga, maka solusi terbaiknya yaitu dengan menggunakan panduan dari Al-quran dan Sunnah (Rosmila et al., 2016).

Pembagian harta warisan dianggap bukan hanya sekedar mempunyai nilai ekonomis (Tirkaamiasa \& Usino, 2015). Kadang timbul perselisihan dalam membagi harta warisan ini yaitu disebabkan perubahan sosial di tengah masyarakat yang masih ada. Yang pertama yaitu disebabkan jumlah warisan yang diterima laki-laki lebih banyak dari perempuan, padahal kebutuhankebutuhan sosial pada dasarnya tidak membedakan jenis kelamin (Wahyudani, 2015). Kedua yaitu hak mewaris anak hasil perkawinan siri, di mana perkawinan ini dilaksanakan sesuai dengan agama, hanya tidak dicatatkan dan masih terjadi di dalam masyarakat Indonesia (Agustina, 2015). Ketiga adalah status anak angkat dalam memperoleh harta warisan dimana hal tersebut sudah diatur pada Peraturan Pemerintah Nomor 54 Tahun 2007 (Karaluhe, 2016).

Dalam Islam wajib hukumnya untuk membagi harta warisan sesuai syariah islamn (Honggowibowo et al., 2017). Hukum waris islam atau ilmu faraidh telah dituliskan di dalam AlQur'an atau sunnah Rasul Shallallahu Alaihi Wasallam, serta kesepakatan para ulama (Satria et al., 2015). Pada dasarnya Agama Islam memberikan kemudahan bagi umat manusia dalam menjalankan setiap syariatnya termasuk juga hukum-hukum Islam (Mulyani et al., 2015).

Selama ini perhitungan jumlah warisan \& penentuan ahli waris yang diperoleh setiap ahli waris masih dilaksanakan dengan cara manual (Mufadhol, 2011). Perhitungan secara manual yang dimaksud adalah seluruh keluarga berkumpul \& jika diantara keluarga tidak ada yang paham akan cara atau prosedur pembagian warisan, keluarga tersebut bisa mengundang seorang ustadz atau yang paham \& telah terbiasa membagikan warisan (Minarni et al., 2018). Hal ini adalah masalah yang sensitif, oleh karena itu diperlukan ketelitian pada saat menghitung harta waris yang akan dibagikan (Septiana et al., 2017).

Expert system yaitu suatu sistem yang beradaptasi menggunakan knowledge manusia yang diinterpretasikan ke dalam komputer supaya komputer bisa menemukan solusi terkait masalah seperti yang biasa dilakukan oleh para pakar (Ilyas \& Anwardi, 2016). Kajian pokok dalam sistem pakar adalah bagaimana memindahkan pengetahuan atau pemahaman dari seorang pakar ke dalam komputer \& bagaimana 
mengambil kesimpulan atau memberikan keputusan berdasarkan knowledge tersebut (Sumadyo, 2013). Pengetahuan ini dipakai sebagai dasar pemahaman oleh expert system untuk berkonsultasi atau menjawab pertanyaan (Amroni, 2016).

Adapun manfaat pengembangan aplikasi perhitungan hak waris dengan menggunakan perangkat android adalah untuk membuat menjadi praktis ahli waris dalam memberikan informasi terkait hasil perhitungan dalam membagi harta waris supaya bisa dibagikan di sosial media terhadap para ahli waris lainnya, memberikan transparansi/keterbukaan terhadap para ahli waris supaya tidak ragu/takut dalam menghitung pembagian harta waris \& memberikan kepraktisan pada saat membagi harta waris untuk para ahli waris dalam bentuk informasi/tulisan hasil dari perhitungan (Hardiyana \& Fahrana, 2018).

Berdasarkan penjelasan terkait problem di atas maka jawaban/solusi yang bisa ditawarkan yaitu dengan merancang software untuk menghitung dan membagi harta warisan sesuai syariat hukum islam. Di dalam penelitian mempergunakan metode Backward Chaining yang akan diimplementasikan sebagai algoritma untuk membangun mesin inferensi dalam expert system, mesin inferensi ini dipakai untuk membuat keputusan atau kesimpulan terkait pihak mana yang bisa memperoleh \& berapa besaran warisan yang didapat oleh ahli waris tersebut serta bisa menggunakannya dimanapun dan kapanpun.

\section{METODE}

\subsection{Model Sistem Pakar}

Sistem pakar yaitu suatu sistem komputer yang mempergunakan teknik penalaran, knowledge \& fakta dalam menyelesaikan problem yang umumnya hanya seorang yang pakar pada bidang tersebut bisa menyelesaikannya. Expert system memberikan added value pada teknologi supaya dapat membantu menangani data dan informasi yang bertambah besar dan rumit.

Model sebuah expert system yang terdiri dari 4 bagian utama yang ditampilkan pada Gambar 1, yaitu (Tirkaamiasa \& Usino, 2015):

1. Knowledge Base

2. Inference Engine

3. User Interface

4. Development Engine

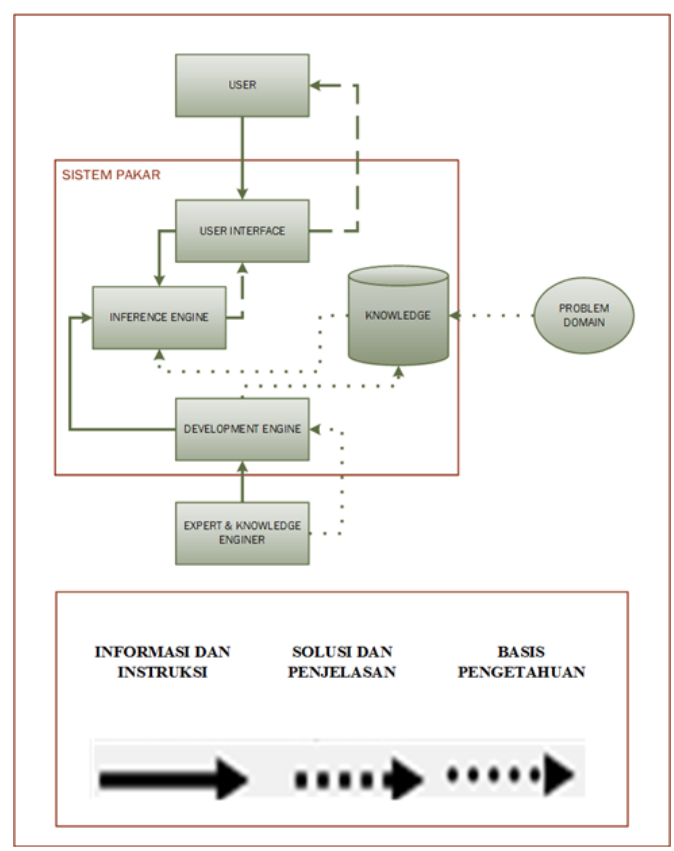

Gambar 1. Model Sistem Pakar

\subsection{Langkah-langkah Penelitian}

Penelitian ini tergolong ke dalam penelitian eksperimen sebab memperlihatkan sebab \& akibat, serta peneliti memperlakuan kepada obyek penelitian "alasan mengapa". Sedangkan jika dari segi jenis informasi yang diproses maka penelitian ini tergolong penelitian kualitatif, sebab informasi/datanya tidak diproses secara 
statistik, tetapi secara langsung dengan studi kasus \& observasi lapangan di Pengadilan Agama. Pada Gambar 2 ditampilkan tahapan pada penelitian ini.

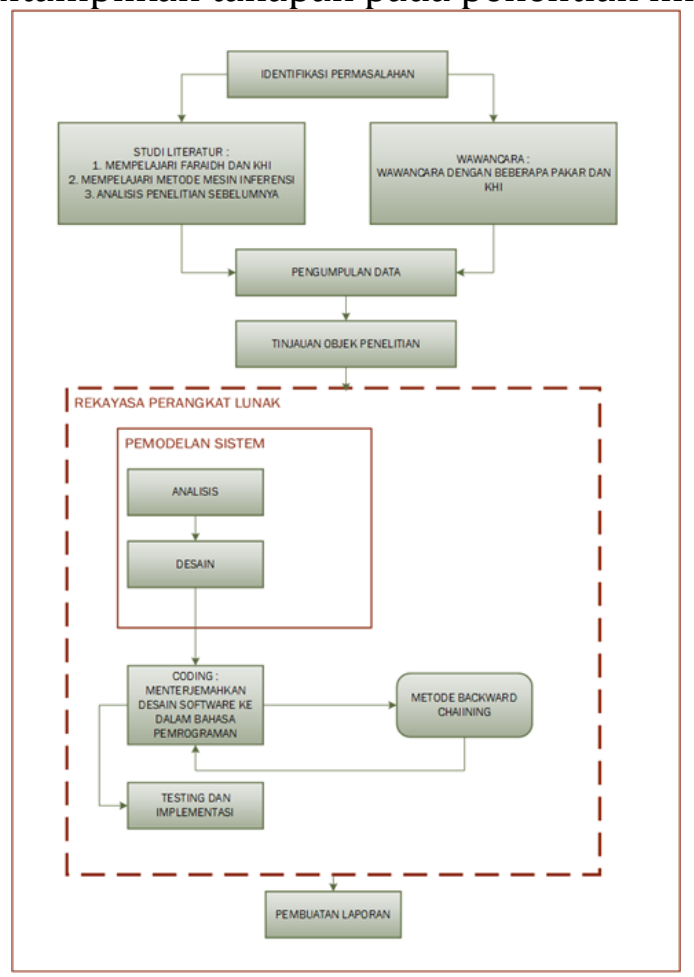

Gambar 2. Langkah-langkah Penelitian

\subsection{Metode Pengumpulan Data}

\section{Wawancara}

Responden dalam wawancara ini adalah Ketua Majelis Hakim salah satu perkara Gugatan Harta Waris di Pengadilan Agama dan beberapa keluarga muslim dalam memyelesaikan kasus waris.

2. Observasi

Proses observasi dilakukan untuk memahami proses bisnis mengumpulkan data, proses analisis, struktur organisasi \& tujuan.

\section{Studi Pustaka}

Diperoleh dari prosiding, buku \& jurnal yang berkaitan terhadap sistem pakar pembagian warisan yang sesuai syariat hukum Islam.

\section{KERANGKA TEORI}

\subsection{Algoritma Sistem Pakar Pembagian Hak Waris}

Flowchart di bawah ini menggambarkan proses bisnis program, di mana bagian yang mempunyai arus yang menampilkan langkah-langkah problem solved. Gambar 3 berikut adalah proses bisnis dari program perancangan software pembagian harta warisan.

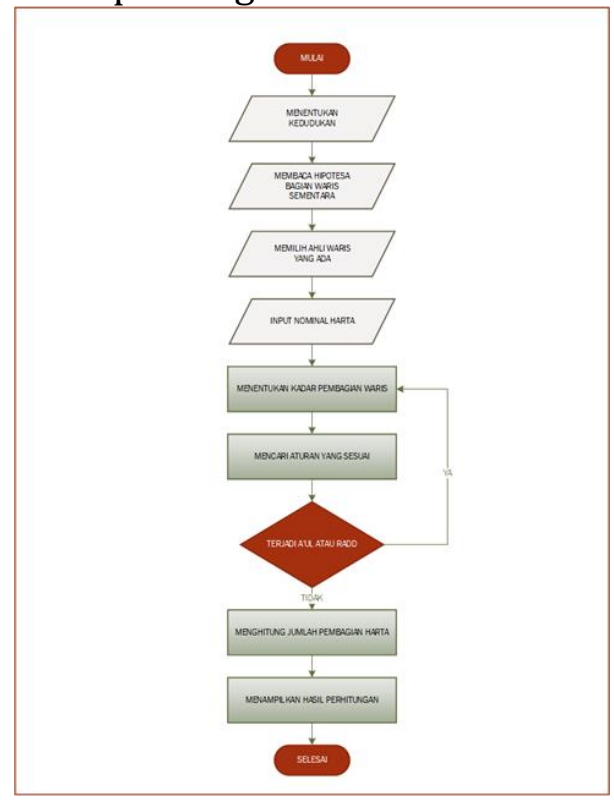

Gambar 3. Flowchart Aplikasi

\subsection{Perancangan Rule Base}

Untuk merepresentasikan aturan pembagian harta waris, maka dibuat pohon keputusan seperti pada Tabel 1 dibawah ini :

Tabel 1. Tabel Keputusan

\begin{tabular}{|c|c|c|c|c|c|c|c|}
\hline \multirow[b]{2}{*}{ Ahli Waris } & \multicolumn{6}{|c|}{ Bagian } & \multirow[b]{2}{*}{ Ket. } \\
\hline & $\begin{array}{l}1 / \\
2 \\
\end{array}$ & $\begin{array}{l}1 / \\
3\end{array}$ & $\begin{array}{l}1 / \\
4 \\
\end{array}$ & $\begin{array}{l}1 / \\
6 \\
\end{array}$ & $\begin{array}{l}1 / \\
8\end{array}$ & $\begin{array}{l}2 / \\
3 \\
\end{array}$ & \\
\hline Suami & $\sqrt{ }$ & & $\sqrt{ }$ & & & & \multirow{10}{*}{ 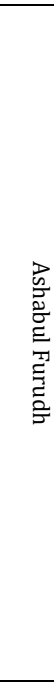 } \\
\hline Istri & & & $\sqrt{ }$ & $\sqrt{ }$ & $\sqrt{ }$ & & \\
\hline Ibu & & $\sqrt{ }$ & & $\sqrt{ }$ & & & \\
\hline $\begin{array}{c}\text { Nenek dari } \\
\text { ibu }\end{array}$ & & & & $\sqrt{ }$ & & & \\
\hline $\begin{array}{c}\text { nenek dari } \\
\text { bapak }\end{array}$ & & & & $\sqrt{ }$ & & & \\
\hline $\begin{array}{c}\text { Saudara } \\
\text { laki-laki dan } \\
\text { perempuan } \\
\text { seibu }\end{array}$ & & $\sqrt{ }$ & & $\sqrt{ }$ & & & \\
\hline Bapak & & & & $\sqrt{ }$ & & & \\
\hline $\begin{array}{c}\text { Kakek dari } \\
\text { bapak }\end{array}$ & & & & $\sqrt{ }$ & & & \\
\hline $\begin{array}{c}\text { Anak } \\
\text { perempuan }\end{array}$ & $\sqrt{ }$ & & & & & $\sqrt{ }$ & \\
\hline $\begin{array}{c}\text { Cucu } \\
\text { perempuan }\end{array}$ & $\sqrt{ }$ & & & $\sqrt{ }$ & & $\sqrt{ }$ & \\
\hline
\end{tabular}

118 | WJIT : Walisongo Journal of Information Technology - Vol.2 No. 2 (2020) 
Perancangan Sistem Pakar Pembagian Harta Waris Menurut Hukum Islam

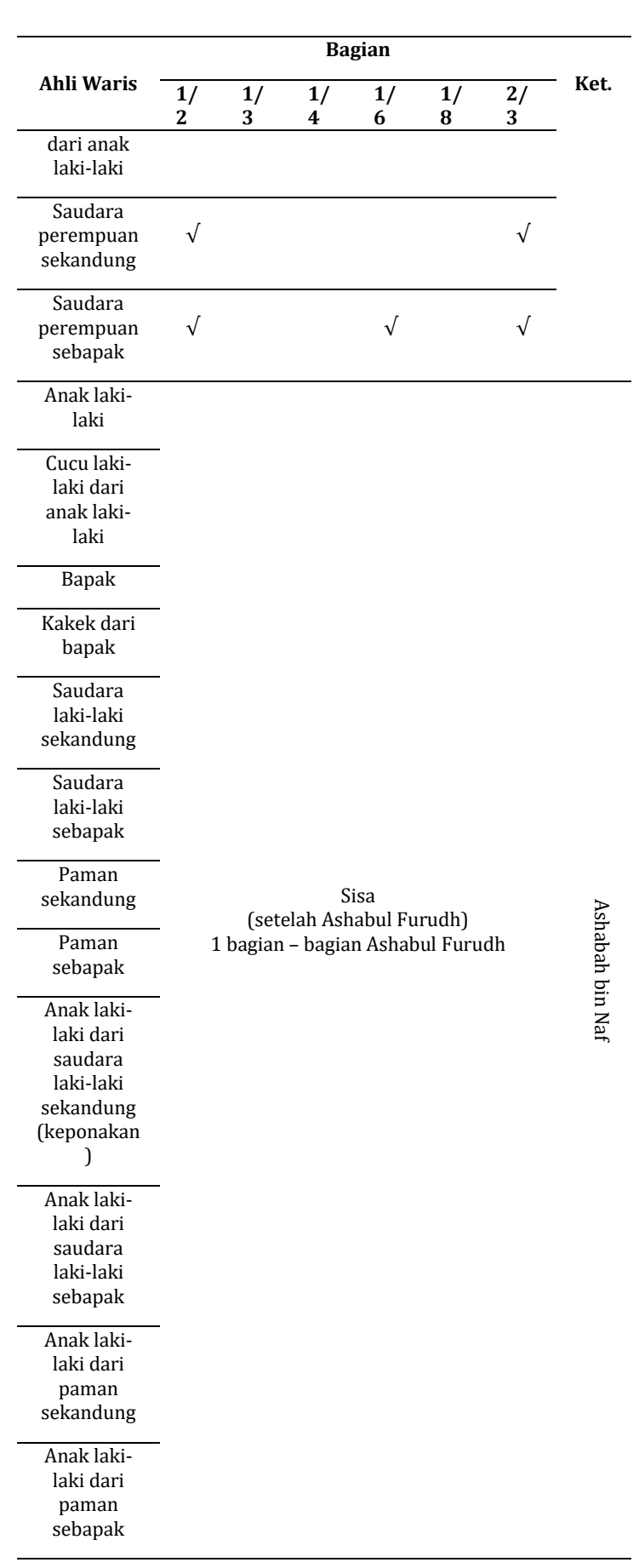

Mulyani dkk. di mana hasil yang didapatkan adalah (Mulyani et al., 2015) : aplikasi tersebut mampu menjadi solusi untuk membantu menyelesaikan permasalahan warisan.

Pada gambar 4 adalah diagram use case yang terdiri 4 use case, dimana use case pertama menentukan besar harta waris kotor sebelum dipotong kewajiban-kewajiban yang harus dikeluarkan, kewajiban-kewajiban tersebut antara lain wasiat, hutang mayit, dan uang biaya pengurusan jenazah. Use case yang kedua menentukan kondisi ahli waris ada/masih hidup atau tidak ada/sudah meninggal, dan atau berapa jumlah ahli waris yang belum meninggal.

Use case yang ketiga proses perhitungan harta waris yang dilakukan oleh mesin inferensi, untuk menentukan apakah ahli waris berhak/tidak/ tertutup untuk mendapatkan harta warisan \& menentukan besaran jumlah warisan yang didapat oleh ahli waris yang berhak.

Use case yang keempat menampilkan informasi status ahli waris berhak atau tidak berhak, dan besar harta waris yang didapatkan bagi ahli waris yang berhak beserta informasi persentase pembagiannya.

Tabel 1 di atas bisa mendeskripsikan kadar yang diperoleh oleh ahli waris sesuai dengan keadaannya.

Penelitian terkait dengan aplikasi perhitungan hak waris secara hukum Islam dengan Metode Backward Chainning sudah pernah dilakukan oleh 


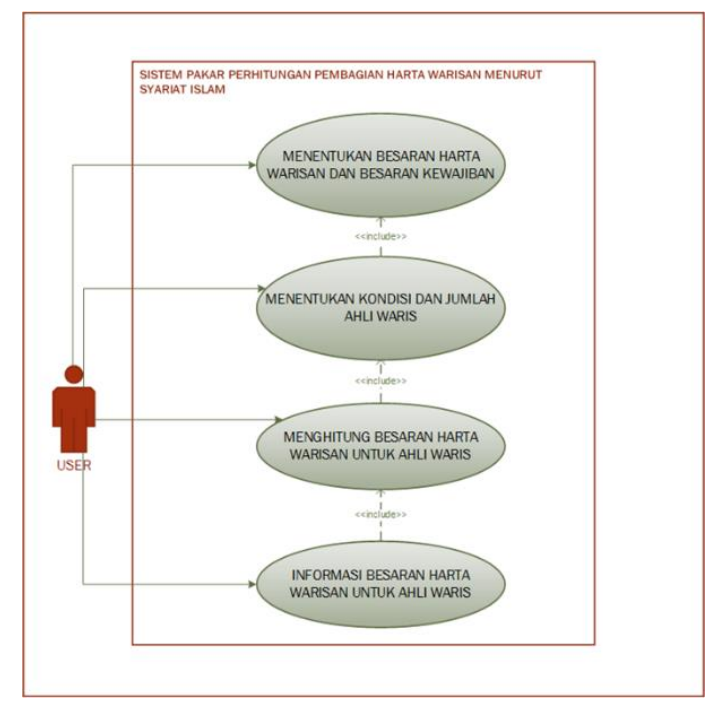

Gambar 4. Diagram use case sistem pakar

Pada gambar 5 adalah diagram class yang terdiri dari 2 class utama beserta atribut-atribut dan metode yang dimiliki setiap classnya.

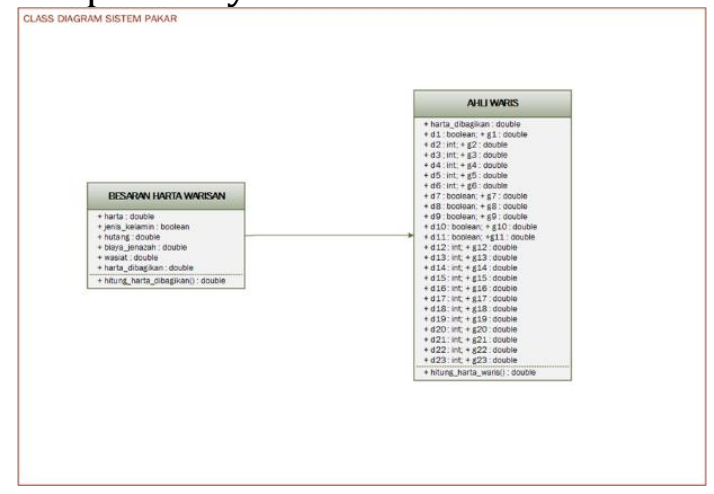

Gambar 5. Diagram class sistem pakar

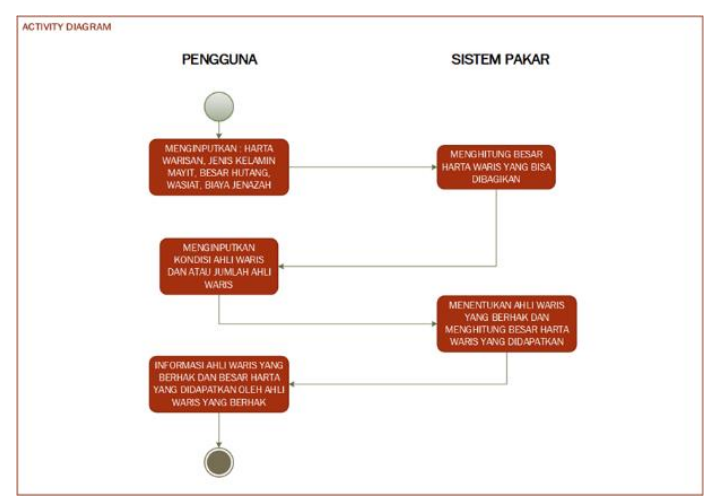

Gambar 6. Diagram activity

Pada gambar 6 adalah diagram activity yang menggambarkan aktifitas yang terjadi antara pengguna dan mesin inferensi.

Pada gambar 7 adalah diagram sequence yang menggambar aliran komunikasi metode antara objek-objek yang dihasilkan dari class-class sistem pakar.

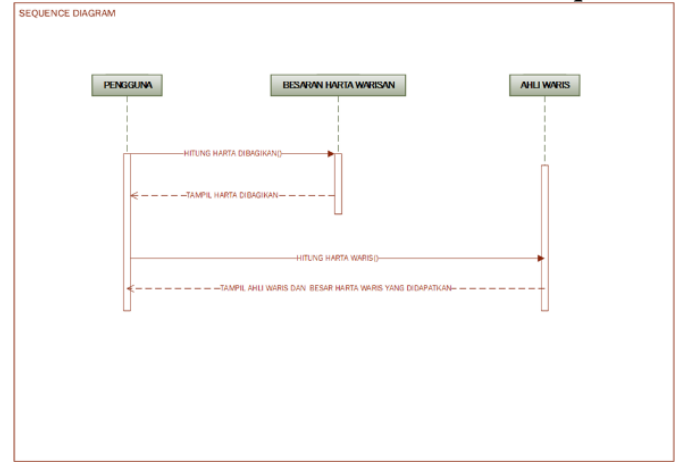

Gambar 7. Diagram sequence

Pada gambar 8 adalah tampilan aplikasi tahap 1, dimana pengguna memasukan besaran harta yang ditinggalkan, jenis kelamin mayit, besaran hutang yang ditinggalkan oleh mayit jika ada, biaya pengurusan jenazah, besaran wasiat yang tinggalkan oleh mayit, dimana besaran maksimum untuk wasiat ini adalah 1/3 dari harta waris.

Pada gambar 9 adalah tampilan aplikasi tahap 2, dimana pengguna memasukan status data seperti pada tabel 1 jika memungkinkan. Masukan yang dilakukan dengan menentukan status ahli waris ada atau tidak ada, atau berapa jumlah ahli waris yang ada.

Pada gambar 10 adalah keluaran yang dihasilkan meliputi siapa saja ahli waris tidak terhalang \& terhalang oleh ahli waris lainnya serta besaran harta waris yang diperoleh. 


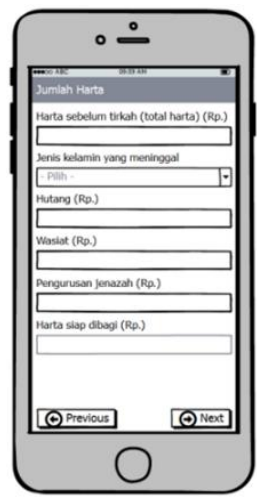

Gambar 8. Tampilan Aplikasi tahap 1

Dalam memasukan informasi ahli waris, aplikasi ini masih harus membutuhkan wawasan para pengguna tentang kondisi-kondisi ahli waris yang akan dimasukkan, seperti syarat-syarat pewarisan (seperti kondisi anak dalam kandungan, ahli waris yang mati bersamaan dengan mayit), sebab-sebab pewarisan, dan faktor-faktor penghalang pewarisan (seperti pembunuhan, ahli waris yang berlainan agama/bukan agama Islam, dan berlainan negara).

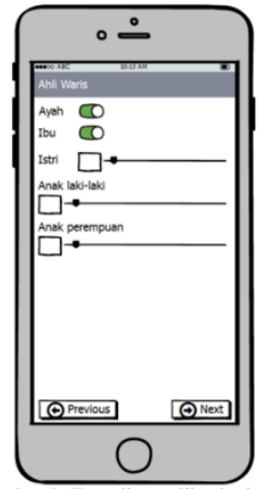

Gambar 9. Tampilan aplikasi tahap 2

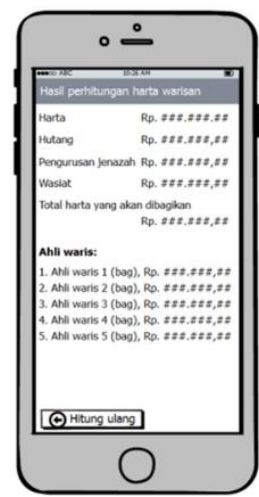

Gambar 10. Tampilan keluaran aplikasi

\section{PEMBAHASAN}

Dalam pengujian metode yang digunakan adalah black-box, merupakan pengujian yang dilaksanakan hanya dengan memperhatikan hasil running program melalui data pengujian \& mengecek fungsi dari software, dimana metode tersebut mempunyai tujuan supaya memperlihatkan fungsi software perihal bagaiman cara beroperasinya, apakah data yang dimasukkan telah sesuai dengan output sebagaimana yang diinginkan dan apakah secara eksternal informasi tersebut disimpan lalu terus diperbaharui.

Tabel 4. Pengujian Black Box pada Program

\begin{tabular}{|c|c|c|c|c|}
\hline $\begin{array}{c}\text { Skenar } \\
\text { io } \\
\text { Penguj } \\
\text { ian }\end{array}$ & $\begin{array}{l}\text { Test } \\
\text { Case }\end{array}$ & $\begin{array}{c}\text { Hasil } \\
\text { yang } \\
\text { diharap } \\
\text { kan }\end{array}$ & $\begin{array}{c}\text { Hasil } \\
\text { Pengujia } \\
\mathbf{n}\end{array}$ & $\begin{array}{c}\text { Kesimp } \\
\text { ulan }\end{array}$ \\
\hline $\begin{array}{l}\text { Test } \\
\text { Form } \\
\text { Login } \\
\text { Penggu } \\
\text { na }\end{array}$ & $\begin{array}{l}\text { Penggun } \\
\text { a } \\
\text { memasu } \\
\text { kkan hak } \\
\text { akses, } \\
\text { nama } \\
\text { dan } \\
\text { passwor } \\
\text { d pada } \\
\text { program }\end{array}$ & $\begin{array}{l}\text { Penggun } \\
\text { a dapat } \\
\text { login } \\
\text { sesuai } \\
\text { dengan } \\
\text { hak } \\
\text { aksesnya }\end{array}$ & $\begin{array}{l}\text { Penggun } \\
\text { a dapat } \\
\text { login } \\
\text { pada } \\
\text { aplikasi } \\
\text { sesuai } \\
\text { dengan } \\
\text { hak } \\
\text { aksesnya }\end{array}$ & Valid \\
\hline $\begin{array}{l}\text { Test } \\
\text { Menu } \\
\text { Utama }\end{array}$ & $\begin{array}{l}\text { Menampi } \\
\text { lkan } \\
\text { layout } \\
\text { menu } \\
\text { utama } \\
\text { setelah } \\
\text { login } \\
\text { dengan } \\
\text { benar }\end{array}$ & $\begin{array}{l}\text { Penggun } \\
\text { a dapat } \\
\text { masuk } \\
\text { pada } \\
\text { layout } \\
\text { menu } \\
\text { utama } \\
\text { setelah } \\
\text { login } \\
\text { dengan } \\
\text { benar }\end{array}$ & $\begin{array}{l}\text { Layout } \\
\text { menu } \\
\text { utama } \\
\text { dapat } \\
\text { tampil } \\
\text { setelah } \\
\text { penggun } \\
\text { a login } \\
\text { dengan } \\
\text { benar }\end{array}$ & Valid \\
\hline $\begin{array}{l}\text { Test } \\
\text { Form } \\
\text { Pertany } \\
\text { aan }\end{array}$ & $\begin{array}{l}\text { Menampi } \\
\text { lkan } \\
\text { form } \\
\text { pertanya } \\
\text { an } \\
\text { keduduk } \\
\text { an } \\
\text { penggun } \\
\text { a dalam } \\
\text { pembagi } \\
\text { an waris }\end{array}$ & $\begin{array}{l}\text { Penggun } \\
\text { a dapat } \\
\text { masuk ke } \\
\text { form } \\
\text { pertanya } \\
\text { an } \\
\text { keduduk } \\
\text { an dalam } \\
\text { pembagi } \\
\text { an waris }\end{array}$ & $\begin{array}{l}\text { Form } \\
\text { pertanya } \\
\text { an } \\
\text { keduduk } \\
\text { an dapat } \\
\text { ditampilk } \\
\text { an dan } \\
\text { penggun } \\
\text { a dapat } \\
\text { menjawa } \\
\text { b } \\
\text { keduduk } \\
\text { annya } \\
\text { dalam } \\
\text { pembagi } \\
\text { an waris }\end{array}$ & Valid \\
\hline
\end{tabular}




\begin{tabular}{|c|c|c|c|c|}
\hline $\begin{array}{c}\text { Skenar } \\
\text { io } \\
\text { Penguj } \\
\text { ian }\end{array}$ & $\begin{array}{l}\text { Test } \\
\text { Case }\end{array}$ & $\begin{array}{c}\text { Hasil } \\
\text { yang } \\
\text { diharap } \\
\text { kan }\end{array}$ & $\begin{array}{c}\text { Hasil } \\
\text { Pengujia } \\
\mathbf{n}\end{array}$ & $\begin{array}{c}\text { Kesimp } \\
\text { ulan }\end{array}$ \\
\hline $\begin{array}{l}\text { Test } \\
\text { Form } \\
\text { Data } \\
\text { Waris }\end{array}$ & $\begin{array}{l}\text { Menampi } \\
\text { lkan } \\
\text { form } \\
\text { data } \\
\text { waris } \\
\text { dan } \\
\text { jumlah } \\
\text { hak } \\
\text { waris } \\
\text { yang } \\
\text { berkedu } \\
\text { dukan } \\
\text { sebagai } \\
\text { hak } \\
\text { waris }\end{array}$ & $\begin{array}{l}\text { Penggun } \\
\text { a dapat } \\
\text { menampi } \\
\text { lkan } \\
\text { form } \\
\text { data } \\
\text { waris } \\
\text { dan } \\
\text { jumlah } \\
\text { hak } \\
\text { waris } \\
\text { yang } \\
\text { berkedu } \\
\text { dukan } \\
\text { sebagai } \\
\text { hak } \\
\text { waris }\end{array}$ & $\begin{array}{l}\text { Form } \\
\text { data } \\
\text { waris } \\
\text { dan } \\
\text { jumlah } \\
\text { hak waris } \\
\text { yang } \\
\text { berkedud } \\
\text { ukan } \\
\text { sebagai } \\
\text { hak waris } \\
\text { dapat } \\
\text { ditampilk } \\
\text { an }\end{array}$ & Valid \\
\hline $\begin{array}{l}\text { Test } \\
\text { Form } \\
\text { Perhitu } \\
\text { ngan }\end{array}$ & $\begin{array}{l}\text { Menampi } \\
\text { lkan } \\
\text { form } \\
\text { perhitun } \\
\text { gan }\end{array}$ & $\begin{array}{l}\text { Penggun } \\
\text { a dapat } \\
\text { menampi } \\
\text { lkan } \\
\text { form } \\
\text { perhitun } \\
\text { gan }\end{array}$ & $\begin{array}{l}\text { Form } \\
\text { perhitun } \\
\text { gan } \\
\text { dapat } \\
\text { ditampilk } \\
\text { an oleh } \\
\text { penggun } \\
\text { a }\end{array}$ & Valid \\
\hline
\end{tabular}

\section{PENUTUP}

\subsection{Kesimpulan}

Berdasarkan hasil penelitian yang telah dilakukan akhirnya didapatkan kesimpulan :

a. Perancangan Sistem pakar ini berfungsi sebagai referensi tentang bagaimana cara pembagian waris menurut syariat Islam sesuai dengan kasus yang ada.

b. Pembagian hak waris dalam Islam mengandung aturan-aturan (rule) tertentu sehingga sangat tepat jika sistem pakar yang akan dibangun adalah sistem yang mempergunakan rules.

c. Penggunaan algortima Backward Chaining mampu menghasilkan basis pengetahuan pada mesin inferensi yang dihasilkan, sehingga mengkonversi aturanaturan hukum waris ke dalam algoritma if-then-else untuk digunakan dalam pengembangan aplikasi sistem pakar

\subsection{Saran}

Setelah mengembangkan sistem pakar ini, ada beberapa saran yang dapat diajukan guna pengembangan sistem lebih lanjut, yaitu:

a. Untuk pengguna sistem yang masih kurang mengetahui tentang istilah-istilah Islam dalam pembagian zakat maka diharapkan untuk menambahkan fasilitas atau fitur yang menjelaskan teori pembagian warisan ini secara terperinci.

b. Sistem pakar ini bisa dikembangkan dengan mengembangkannya menjadi berbasis android. 


\section{REFERENCES}

Agustina, E. (2015). Akibat Hukum Hak Mewaris Anak Hasil Perkawinan Siri Berbasis Nilai Keadilan. Jurnal Pembaruan Hukum, 2(2), 381-390.

Amroni. (2016). Penerapan Sistem Pakar Berbasis Rule Dalam Pembagian Zakat Menurut Hukum Islam. Jurnal Ilmiah Media Processor, 11(1), 601-615.

Ardhilla, T. L., \& Novrina. (2016). Aplikasi Sistem Pakar Ilmu Faraidh Berbasis Web Menggunakan Metode Forward Chaining. Jurnal Informatika Dan Komputer, 21(3), 27-36.

Hardiyana, B., \& Fahrana, E. (2018). Aplikasi Penerapan Syariat Islam Pada Pembagian Harta Waris Berbasis Android. Jurnal Teknologi Dan Informasi, 8(1), 25-32. https://doi.org/10.34010/jati.v8i1.907

Honggowibowo, S. A., Indrianingsih, Y., \& Umami, A. S. (2017). Sistem Pakar Dengan Metode Forward Chaining Untuk Menentukan Pembagian Warisan Menurut Hukum Islam Menggunakan Algoritma Best First Search. Compiler, 6(1), 8-16.

Ilyas, \& Anwardi. (2016). Sistem Pakar Pembagian Harta Waris Menurut Hukum Islam dengan Metode Forward Chaining Berbasis Web. Seminar Nasional Teknologi Informasi, Komunikasi Dan Industri (SNTIKI 8), November, 138-152.

Karaluhe, S. S. (2016). Kedudukan Anak Angkat Dalam Mendapatkan Harta Warisan Ditinjau Dari Hukum Waris. Lex Privatum, 4(1), 166-174.

Minarni, D., Isa, I. G. T., \& Yanik, A. (2018). Aplikasi Bagi Waris Islam dengan Metode Forward Chaining berbasis Web. Jurnal Online Informatika, 2(2), 127-133.

Mufadhol, M. (2011). Pemanfaatan Pemrograman Visual Untuk Aplikasi Sistem Pembagian Warisan Menggunakan Metode Prototype Paradigma Pada Sistem Pakar. Jurnal Transformatika, 9(1), 28-36.

Mulyani, E. D. S., Mufizar, T., \& Novianti, I. (2015). Perancangan Aplikasi Sistem Pakar Pembagian Harta Waris Menurut Islam Menggunakan Metode Backward Chaining. Seminar Nasional Teknologi Informasi Dan Multimedia 2015, 76-84.

Rosmila, Yamin, M., \& Tajidun, L. (2016). Aplikasi Pembagian Harta Waris Menurut Hukum Islam Dengan Menggunakan Metode Algoritma Genetika. SemanTIK, 2(2), 225-236.

Rumambi, N. A. (2015). Sistem Pakar Penentuan Hak Waris Berdasarkan Hukum Islam yang Sesuai Dengan Al-Qur'an dan As-Sunnah yang Shahih. Jurnal Sistem Dan Teknologi Informasi, 3(2), 59-62.

Satria, E., Tresnawati, D., \& Roji, F. F. (2015). Pengembangan Aplikasi Pembagian Waris Islam Berbasis Android. Jurnal Algoritma, 1(1), 1-7.

Septiana, Y., Kurniadi, D., \& Mulyani, A. (2017). Perancangan Program Aplikasi Faraidh sebagai Sistem Pendukung Keputusan Pembagian Harta Waris Berorientasi Solver. Jurnal Algoritma, 14(2), 474-480.

Sumadyo, M. (2013). Sistem Pakar Pembagian Waris (Faro'idl), Studi Kasus Kepakaran Kyai Rochmadi. Jurnal Penelitian Ilmu Komputer, System Embedded \& Logic, 1(2), 98-106.

WJIT : Walisongo Journal of Information Technology - Vol.2 No. 2 (2020) 
Tirkaamiasa, T., \& Usino, W. (2015). Sistem Pakar Pembagian Waris Menggunakan Metode Forward Dan Backward Chaining. Krea-TIF, 3(2), 61-83.

Wahyudani, Z. (2015). Perubahan Sosial Dan Kaitannya Dengan Pembagian Harta Warisan Dalam Perspektif Hukum Islam. Jurnal Ilmiah ISLAM FUTURA, 14(2), 166-189. 